\title{
Predation of Gecarcinus quadratus (Decapoda: Gecarcinidae) by Aramides cajaneus (Gruiformes: Rallidae) in Costa Rica
}

\section{Depredación de Gecarcinus quadratus (Decapoda: Gecarcinidae) por Aramides cajaneus (Gruiformes: Rallidae) en Costa Rica}

\author{
Sergio Villegas-Retana ${ }^{1 *} \&$ Jorge Picado-Masí ${ }^{2}$
}

\begin{abstract}
Gecarcinus quadratus is a land crab preyed upon by some species, but there is little information about the genera and species of these predators. This scientific note presents the first record of Aramides cajaneus preying upon G. quadratus. This observation occurred during daylight in May 2021 in Costa Rica, and contributes to the knowledge about the natural history, behavior and ecology of these species.
\end{abstract}

Keywords: behavior, diet, Gray-cowled Wood-Rail, Halloween Crab, natural history

\section{RESUMEN}

Gecarcinus quadratus es un cangrejo terrestre depredado por algunas especies, sin embargo, hay poca información en el nivel de género y especie de sus predadores. Esta nota científica presenta el primer registro de Aramides cajaneus depredando a G. quadratus. La observación ocurrió durante el día, en mayo del 2021, en Costa Rica y contribuye al conocimiento sobre la historia natural, comportamiento y la ecología de estas especies.

Palabras clave: comportamiento, dieta, Cangrejo de Halloween, Rascón Cuelligrís, historia natural

1 Escuela de Biología, Universidad de Costa Rica, San Pedro de Montes de Oca, 11501-2060 San José, Costa Rica. sergio.villegas@ucr.ac.cr* ORCID: http://orcid.org/0000-0002-9579-1479

2 Professional certified tour guide, Manuel Antonio National Park, Quepos, 60601 Puntarenas, Costa Rica. picadomasisjorge@gmail.com, ORCID: https://orcid.org/0000-0003-4493-9346 


\section{INTRODUCTION}

Gecarcinus quadratus (de Saussure, 1853) is a terrestrial crab that inhabits neotropical coastal forests, and is distributed from Florida, through the Antilles and Central America to Guyana on the Atlantic Coast, and from Mexico to Peru on the Pacific Coast (Burggren \& McMahon, 1988; Sherman, 2002). It is fossorial, its populations (of up to six crabs $\mathrm{m}^{-2}$ ) extend approximately $600 \mathrm{~m}$ inland from the shore in coastal forests, and its activity outside the burrow increases during the rainy season (Von Prahl \& Manjarrés, 1984; Sherman, 2002; Sherman, 2003). It has been reported as being preyed upon by Crocodylus acutus (Cuvier, 1807), Procyon lotor (Linnaeus, 1758), some birds and perhaps other crabs (Carrillo et al. 2001; Perger et al. 2013; Cupul-Magaña et al. 2015; Villagrán-Colón et al. 2016). G. quadratus may have developed adaptations to high levels of predation (Perger, 2013), but there is little information about the genera and species of these predators.

On the other hand, Aramides cajaneus (Statius Muller, 1776) is a bird distributed from southwestern Costa Rica southwards to northern Argentina, from lowlands up to 2,300 m.a.s.l. (Stiles \& Skutch, 1989; Taylor, 2020). It inhabits wet ground along the sides of streams, as well as swamps, secondary growth and deciduous woodlands, mangroves, marshes and marshy thickets, rice and cane fields, seasonal pools and scrubby pastures, as long as they include wet and shaded areas (Stiles \& Skutch, 1989; Taylor, 2020). Its diet is diverse and includes mostly invertebrates (including crabs), but also small vertebrates such as frogs, as well as seeds and fruits (Stiles \& Skutch, 1989; Taylor, 2020). It also feeds on the feces of giant otters in latrines (Leuchtenberger et al. 2012).

Among the crab species reported as prey of $A$. cajaneus are: Uca rapax (Smith, 1870), U. mordax (Smith, 1870), U. leptodactyla (Rathbun in Rankin, 1898), U. uruguayensis (Nobili, 1901), and Callinectes danae (Smith, 1869; Silva \& Olmos 2015). It has also been observed consuming droppings of horses and $P$. lotor; in the latter, perhaps looking for remains of crab exoskeletons, possibly of the genera Gecarcinus and Cardiosma (Skutch, 1994; Solano-Ugalde, 2005). Nevertheless, there are no reports of A. cajaneus preying on G. quadratus. The following report represents the first record of an event of this kind.

\section{MATERIALS AND METHODS}

The event occurred on the El Perezoso Trail, at Manuel Antonio National Park, Quepos, Puntarenas, Costa Rica ( $9^{\circ} 23^{\prime} \mathrm{N}, 84^{\circ} 8^{\prime} \mathrm{W}$; 23 m.a.s.1.). 
On 24 May 2021, at $0800 \mathrm{~h}$, the second author observed an individual of A. cajaneus preying on an individual of G. quadratus during a guided tour. The crab was coming out of the forest and the wood-rail followed, pecking at it. When they reached the trail, the crab tried to cross it and escape, but the wood-rail took advantage to get close to it, catching one of its walking legs with its bill and flipping it on its back. It began to hammer at the crab with its bill to break its shell, while the crab tried to defend itself by raising its chelipeds (Fig. 1). Finally, the bird killed the crab and carried it into the forest as a large group of people approached the site. The whole event lasted at least 2 minutes.

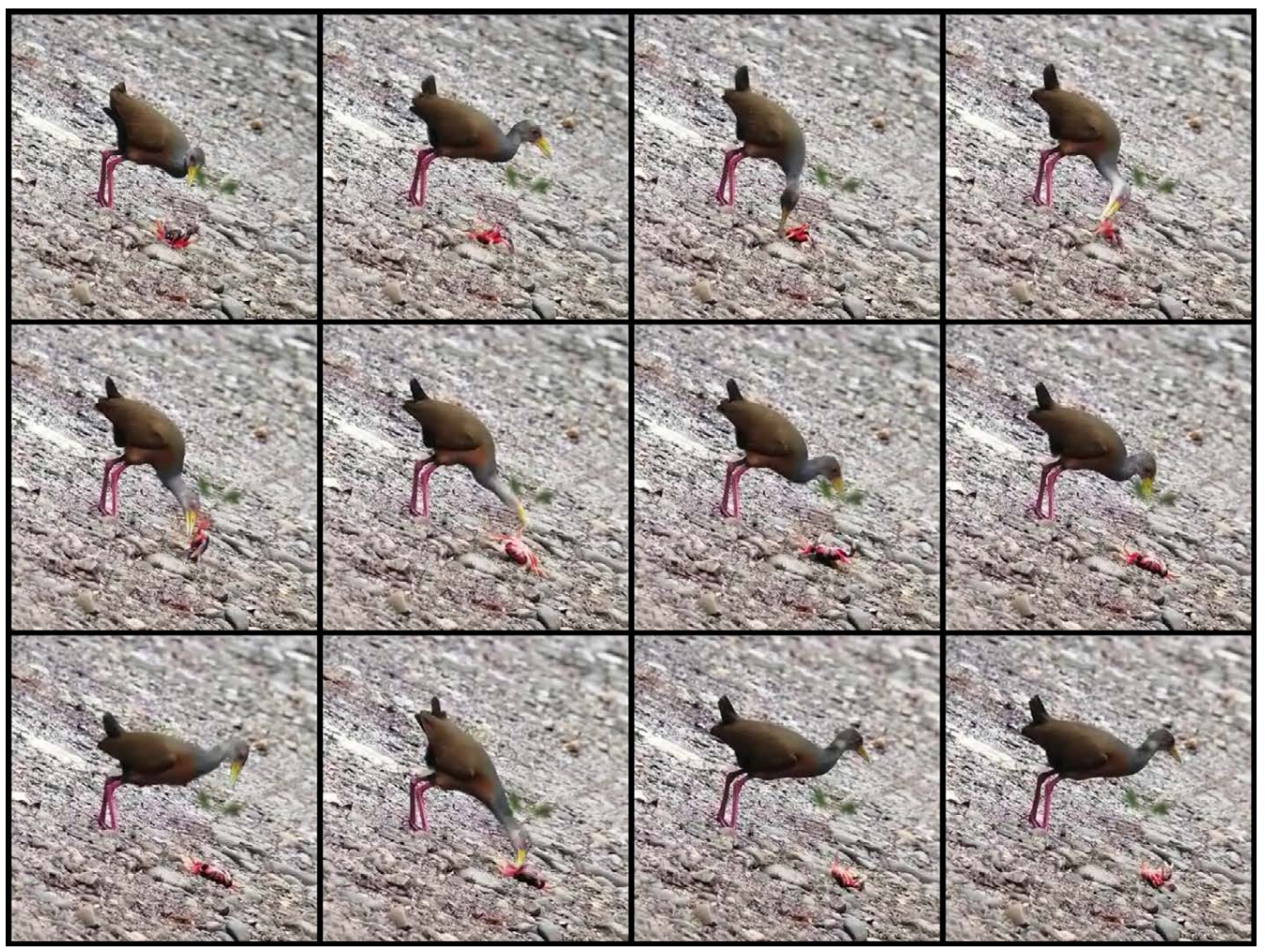

Fig. 1. Aramides cajaneus preying on Gecarcinus quadratus, Manuel Antonio National Park, Costa Rica, 2021 (Photos from a video recorded by Jorge Picado; the pictures should be viewed from left to right in each row and the rows should be viewed from top to bottom)

Fig. 1. Aramides cajaneus depredando a Gecarcinus quadratus, Parque Nacional Manuel Antonio, Costa Rica, 2021 (Secuencia de fotos del vídeo grabado por Jorge Picado, ver de izquierda a derecha y de arriba hacia abajo) 


\section{RESULTS AND DISCUSSION}

Land crabs are preyed upon by a wide range of vertebrates (Burggren \& McMahon, 1988). Many of them are birds, which have been identified at the species level (Burggren \& McMahon, 1988; Wolcott \& Wolcott, 1982; Silva \& Olmos 2015). In the case $G$. quadratus, we only found two predators identified to this level (Carrillo et al. 2001; Cupul-Magaña et al. 2015). Birds have also been reported as predators of G. quadratus, but there is no specific data on their taxonomy; this is the first study in which an avian predator is identified at the species level.

Some crab species are also an important part of the diet of $A$. cajaneus (Silva \& Olmos 2015; Taylor, 2020). In mangroves, for example, this bird preys heavily on crabs (Taylor, 2020). In this sense, it could be that this crab is a regular part of the diet of $A$. cajaneus, along with other crab species (Silva \& Olmos 2015), but it is necessary to carry out further studies to determine its diet in more detail. It is possible that the wood-rail took advantage of the crab crossing the trail to hunt it.

The wood-rail hammered its prey with its bill to destroy its shell, a behavior which has been reported when this species preys on snails (Taylor, 2020). While the crab tried to defend itself by raising its chelipeds, it was unable to use them successfully or use autonomy in response to the attack, which is a defensive system used by G. quadratus to defend itself effectively while wandering far from a burrow or retreat (Robinson et al. 1970). Likewise, the Halloween Crab is nocturnal (Sherman, 2002; Sherman, 2003), and A. cajaneus apparently often feeds at night (Taylor, 2020), but this observation occurred at 08:00 h. However, both species can also engage in diurnal activity (Von Prahl \& Manjarrés, 1984; Solano-Ugalde, 2005), so it is possible that this was an opportunistic event.

Knowledge about predation is one of the initial steps to understand the ecology and ethology of animals (Curio, 2012). Identifying species of predators provides basic information to study its impact on the life histories of prey and their defense mechanisms, as well as the hunting behavior and diet of predators (Robinson et al. 1970; Curio, 2012; Perger et al. 2013). The evidence presented here contributes to the knowledge about the natural history, behavior, and ecology of both G. quadratus and A. cajaneus.

\section{ACKNOWLEDGEMENTS}

We gratefully acknowledge to Ingo Wehrtmann for suggestions and recommendations for preparing the manuscript. We also want to thank the two anonymous reviewers for suggestions that improved the manuscript. 


\section{REFERENCES}

Burggren, W. \& McMahon, R. (1988). Biology of the land crabs. EE. UU.: Cambridge University Press.

Carrillo, E., Wong, G. \& Rodríguez, M. A. (2001). Hábitos alimentarios del mapachín (Procyon lotor) (Carnivora: Procyonidae) en un bosque muy húmedo tropical costero de Costa Rica. Rev. Biol. Trop., 49(3-4), 1193-1197. https://doi.org/10.15517/rbt.v49i3-4

Cupul-Magaña, F. G., Mc Cann, F. \& Escobedo-Galván, A. H. (2015). Observación del consumo de presas en el cocodrilo americano (Crocodylus acutus Cuvier, 1807): registro fotográfico. Quehacer Cientifico en Chiapas, 10(2), 11-15.

Curio, E. (2012). The ethology of predation. EE. UU.: Springer Science \& Business Media. Leuchtenberger, C., Ribas, C., Magnusson, W. \& Mourão, G. (2012). To each his own taste: latrines of the giant otter as a food resource for vertebrates in Southern Pantanal, Brazil. Stu. Neotrop. Fauna Environ., 47(2), 81-85. http://dx.doi.org /10.1080/01650521.2012.697690

Perger, R., Cortes, J. \& Pacheco, C. (2013). Closing a distributional gap of over 3 $000 \mathrm{~km}$ and encountering an invisible barrier: new presence/absence data for Johngarthia planata Stimpson, 1860 (Decapoda, Brachyura, Gecarcinidae) for Central America and biogeographic notes on East Pacific Gecarcinidae. Crustaceana, 86(3), 268-277. https:// doi.org/10.1163/15685403-00003172

Robinson, M. H., Abele, L. G. \& Robinson, B. (1970). Attack autotomy: a defense against predators. Sci., 169(3942), 300-301. https://doi.org/10.1126/ science.169.3942.300

Sherman, P. M. (2002). Effects of land crabs on seedling densities and distributions in a mainland neotropical rain forest. $J$.
Trop. Ecol., 18(1), 67-89. https://doi. org/10.1017/S0266467402002043

Sherman, P. M. (2003). Effects of Land Crabs on Leaf Litter Distributions and Accumulations in a Mainland Tropical Rain Forest. Biotropica, 35(3), 365-374. https://doi.or$\mathrm{g} / 10.1111 / \mathrm{j} .1744-7429.2003 . t b 00590 . x$

Silva, R. \& Olmos, F. (2015). Distribution and natural history of the mangrove-dwelling Gray-necked Wood-Rail, Aramides cajaneus avicenniae Stotz, 1992, in southeastern Brazil. Rev. Bras. Ornitol., 23(4), 368376. https://doi.org/10.1007/BF03544310

Skutch, A. F. (1994). The Gray-necked WoodRail: Habits, food, nesting, and voice. The Auk, 111(1), 200-204. https://doi. org/10.2307/4088524

Solano-Ugalde, A. (2005). Observaciones de coprofagismo por parte de Aramides cajanea (Rallidae: Aves) en el Refugio de Vida Silvestre Curú, Puntarenas. Zeledonia, 9(1), 33-34.

Stiles, G. \& Skutch, A. (1989). A Guide to the Birds of Costa Rica. EE. UU.: Cornell University Press.

Taylor, B. (2020). Gray-cowled Wood-Rail (Aramides cajaneus). In Billerman, S. M. Keeney, B. K. Rodewald, P. G. \& Schulenberg, T. S. (Eds.). Birds of the World (version 1.0). EE. UU.: Cornell Lab of Ornithology. https://doi. org/10.2173/bow.gycwor1.01

Villagrán-Colón, E. R., Ramírez-Aguilar, A. M. \& Monzón-Pineda, A. E. (2016). Distribución, aspectos biológicos y ensayo de cultivo de los cangrejos de manglar Cardisoma crassum (Smith, 1870) y Gecarcinus quadratus (Saussure, 1853) en el área del Canal de Chiquimulilla, en los municipios: Taxisco, Guazacapán y Chiquimulilla de Santa Rosa, Guatemala. (Informe Final). Universidad de San Carlos de Guatemala, Guatemala. Sin editorial. 
Von Prahl, H. \& Manjarrés, G. (1984). Cangrejos Gecarcinidos (Crustacea; Gecarcinidae) de Colombia. Caldasia, 149-168. https://www.jstor.org/ stable/23641468

Wolcott, T. G. \& Wolcott, D. L. (1982). Larval loss and spawning behavior in the land crab Gecarcinus lateralis (Freminville). J. Crustacean. Biol., 2(4), 477485. https://doi.org/10.2307/1548089 